\title{
Growth behaviour of apple cultivars on different apple rootstock
}

\author{
Fazal Rabi ${ }^{1}$, Abdur Rab ${ }^{1}$, Nadia Bostan ${ }^{1 *}$, Muhammad Sajid ${ }^{1}$ and \\ Khalil-UR-Rahman ${ }^{2}$ \\ 1. Department of Horticulture, University of Agriculture Peshawar, Pakistan \\ 2. Agriculture Research Institute (N) Mingora Swat, Pakistan \\ *Corresponding author's email: nadia.bostan11@gmail.com \\ Citation \\ Fazal Rabi, Abdur Rab, Nadia Bostan, Muhammad Sajid and Khalil-UR-Rahman. Growth behaviour of apple \\ cultivars on different apple rootstock. Pure and Applied Biology. Vol. 5, Issue 2, 2016, pp339-344. \\ http://dx.doi.org/10.19045/bspab.2016.50044
}

Received: 28/10/2015

Revised: 21/03/2016

Accepted: 02/04/2016

Online First: 18/04/2016

\section{Abstract}

The growth behavior of apple cultivars on apple rootstocks was investigated at Agricultural Research Institute (ARI) Swat during 2012. The experiment was laid out in Randomized Complete Block Design (RCBD) with two factors factorial arrangements having rootstocks (MM111, MM106, M26, M9 and Crab Apple) and apple cultivars (Treco Gala, Spartan, Mondial Gala, Royal Gala and Gala Must) replicated three times. Apple cultivar Gala Must significantly $(\mathrm{P}>0.05)$ showed maximum leaf area $\left(33.62 \mathrm{~cm}^{2}\right)$ and root length $(10.49 \mathrm{~cm})$, while cultivar Treco Gala showed earliest sprouting (44.93 days) and maximum number of branches (1.60) plant $^{-1}$. On the other hand rootstocks significantly $(\mathrm{P}>0.05)$ effected different parameters. Rootstock Crab Apple showed maximum leaf area $\left(27.81 \mathrm{~cm}^{2}\right)$ and root length $(18.87 \mathrm{~cm})$. While early sprouting (43.60days) and maximum number of branches (1.53) plant $^{-1}$ was recorded on rootstock MM106 and M26 respectively. Significant interaction was observed between rootstocks and cultivars for some of the growth parameters however greater leaf area $\left(40.8 \mathrm{~cm}^{2}\right)$ and root length $(20.1 \mathrm{~cm})$ was recorded in cultivar Gala Must grafted on apple rootstock Crab Apple, while maximum number of shoots (1.79) plant $^{-1}$ was noted in cultivar Treco Gala grafted on rootstock M-26. Crab apple rootstock and cultivar Gala Must showed best result in most growth parameters and thus is recommended for better growth of apple plants.

Key words: Apple cultivar; Rootstock; Growth behavior

\section{Introduction}

Apple (Malus sylvestris) is a deciduous fruit plant which belongs to the family Rosaceae and sub family Pomoidea with a basic chromosome number 17. The botanical name of apple is used as Pyrus alus $\mathrm{L}$. Malus sylvestris and Malus malus. But the most common name is Pyrus malus L. It is one of the famous and most important fruits of temperate zone which supports much of the population of the world. It has a beautiful shape with good taste that's why it is called king of deciduous fruits. The genus malus has 25 species and several sub species of crab apple. It is grown in various parts of Pakistan i.e. Murree, Chitral, Swat, Gilgit, Hazara and upland of Quetta and Qalat. Apple thrives well and produces the best quality in relatively long, cool and slow growing season, the type of climate which usually prevails at altitude of $1700-2500 \mathrm{~m}$. For apples, rain fall is important and $750 \mathrm{~mm}$ 
rainfall well distributed throughout the year is ideal and mean summer temperature up to $27^{\circ} \mathrm{C}$ is necessary [1]. In Pakistan, apple is grown on about 113 thousand hectares with an annual production of about 441 thousand metric tons. Khyber Pakhtoonkhwah contributes 130 thousand tons of apples from 9700 hectares [2]. Apple trees are generally trained to a central leader or a delayed open center system. Apple trees are budded on crab apple, on various East Malling types, and on seedling of some commercial apple varieties. In apples the vegetative propagation is done by grafting or budding. Some important methods of grafting of apples are whip or tongue grafting and cleft grafting, for budding, the ring and T-budding techniques are often practiced [1]. M-9 is the most dwarfing rootstock of the commercial $\mathrm{M}$ series for apple. It produces a tree only $20-40 \%$ of the standard size. MM-106 is vigorous, shoots somewhat spreading, wood covered with fairly profuse whitish pubescence somewhat swollen at node [3]. M-26 rootstock is a cross of MM-106 and M-9, and produces a tree slightly larger than M-9 and is well adopted for high density planting [4]. MM111 root stock gives a tree about the same size as that on M-26 that is about $65 \%$ of standard size. [3]. Crab Apple form small round headed tree with compact crown growth. It is slow bearing; the yield is variable but generally low. The tree size is $100 \%$ as compared to the other clonal rootstocks. It is tolerant to fire blight disease of apple [4]. In Malakand division in general and in Swat in particular, the nursery business is on the top. So many people of the area are engaged in this business and earning a lot. The study was conducted at Agricultural Research Institute Swat with the objective to observe the growth behavior of different cultivars on the same and different rootstocks.

\section{Materials and methods}

The experiment entitled "Growth behavior of apple cultivars on different apple rootstock" was carried out in Agriculture Research Institute Mingora Swat, during 2012. The experiment was laid out in Randomized Complete Block Design (RCBD) with two factors factorial arrangements. Total numbers of treatments were twenty five, replicated three times. Plant to plant distance was kept $30 \mathrm{~cm}$ while row to row $60 \mathrm{~cm}$ accordingly. The thickness of rootstock and scion was almost the same for maximum contact of the cambia of both parts. The live material i.e. Rootstocks (MM111, MM106, M26, M9 and Crab Apple) and scion wood (Treco Gala, Spartan, Mondial Gala, Royal Gala and Gala Must) was taken from the same institute. Grafting on the rootstocks was done in $1^{\text {st }}$ week of March, all the cultural practices were applied. Data was recorded in $2^{\text {nd }}$ week of November when all the vegetative growth stops. Data was taken on days to sprouting by counting the number of days from the date of grafting to $50 \%$ sprouting of graft for each treatment in each replication and then mean was worked out. For data on leaf area $\left(\mathrm{cm}^{2}\right)$, the leaf area for 5 randomly selected plants was measured with the help of leaf area measuring meter for each treatment, and their mean was calculated. Number of shoots plant ${ }^{-1}$ was counted for each treatment in each replication of five randomly selected plants and then the means were worked out. For data on root length, the root length for 5 randomly selected plants was measured with the help of measuring tape for each treatment, and their mean was calculated. All the data noted on plant growth parameters was subjected to analysis of variance (ANOVA) process to verify differences among various treatments and their interactions. When differences were significant least significant difference (LSD) 
test was used for mean differences. Computer statistical software MSTATC was applied for calculating both ANOVA and LSD [5].

\section{Results and discussion}

Days to 50\% sprouting

The data recorded for days to sprout is presented in Table 1 was processed for statistical analysis and significant difference was revealed among different rootstocks and cultivars while non-significant difference was shown for their interaction. The data regarding days to sprouting indicated that delay sprouting (50.33 days) was in apple rootstock MM-111 which was at par with the Crab apple rootstock (49.80 days), M-9 (49.13 days) and M-26 (48.46 days).
Whereas, MM-106 rootstock showed early sprouting (43.60 days). As concerned apple cultivars, Spartan cultivar showed delayed sprouting (53.46 days) which significantly varied from the rest of the treatment followed by Mondial gala (49.46 days) whereas the earliest sprouting (44.93 days) was observed in apple cultivar Treco Gala. Difference in days to sprouting might be due to the reason that Gala apple matures early (August) as compared to Spartan (September) [6]. These results are in the markup with [7], who reported the result of experiment that early maturing season's cultivars sprouts and blooms early. On the hand rootstock MM-111 is compatible and vigorous rootstock and hence sprouts early.

Table 1. Days to 50\% sprouting of apple grafting as affected by rootstocks and cultivars

\begin{tabular}{lllllll}
\hline \multirow{2}{*}{ Cultivars } & \multicolumn{7}{c}{ Rootstocks } & \\
\cline { 2 - 6 } & MM111 & MM106 & M26 & M9 & $\begin{array}{c}\text { Crab } \\
\text { apple }\end{array}$ & Mean \\
\hline Treco gala & 47.66 & 41.66 & 47.66 & 46.66 & 41.00 & $44.93 \mathrm{c}$ \\
Spartan & 53.33 & 52.33 & 54.66 & 54.00 & 54.00 & $53.46 \mathrm{a}$ \\
Mondial gala & 52.00 & 43.00 & 52.00 & 48.66 & 51.66 & $49.46 \mathrm{~b}$ \\
Royal gala & 49.00 & 40.33 & 45.00 & 46.66 & 54.33 & $47.06 \mathrm{bc}$ \\
Gala must & 50.66 & 40.66 & 44.00 & 49.66 & 48.00 & $46.40 \mathrm{c}$ \\
\hline Mean & $50.33 \mathrm{a}$ & $43.60 \mathrm{~b}$ & $48.46 \mathrm{a}$ & $49.13 \mathrm{a}$ & $49.80 \mathrm{a}$ & \\
\hline
\end{tabular}

\section{Leaf area $\left(\mathrm{cm}^{2}\right)$}

The data recorded for leaf area $\left(\mathrm{cm}^{2}\right)$ is presented in Table 2 was processed for statistical analysis and significant difference was revealed among different cultivars, rootstock ad their interaction. The data regarding leaf area indicated that maximum leaf area $\left(31.15 \mathrm{~cm}^{2}\right)$ was noted in apple rootstock Crab Apple followed by rootstock MM-111 (27.81 cm $\left.\mathrm{cm}^{2}\right)$ MM-106 $\left(26.15 \mathrm{~cm}^{2}\right)$ and M-26(22.95 $\left.\mathrm{cm}^{2}\right)$ whereas M-9 rootstock, had less leaf area $\left(20.99 \mathrm{~cm}^{2}\right)$. As concerned apple cultivars, Gala Must attain maximum leaf area $\left(33.62 \mathrm{~cm}^{2}\right)$ which significantly varied from the rest of the treatment followed by Treco Gala (30.21 $\left.\mathrm{cm}^{2}\right)$, Mondial Gala $\left(25.93 \mathrm{~cm}^{2}\right)$ whereas the minimum leaf area $\left(16.83 \mathrm{~cm}^{2}\right)$ was observed in apple cultivar Spartan. As concerned interaction maximum leaf area $\left(40.8 \mathrm{~cm}^{2}\right)$ was recorded in apple cultivar Gala Must grafted on Crab Apple rootstock of apple, while the graftage of apple cultivar Spartan on M-9 rootstock attains minimum leaf area $\left(12.05 \mathrm{~cm}^{2}\right)$. As clear from the studied result that apple cultivar grafted on vigorous apple rootstock has greater leaf area. These results are in mark up with the previous study who reported that scions on low-vigor rootstocks had $50 \%$ or less leaf area than scions on the most vigorous rootstocks [8]. It was described that scions on low-vigor rootstocks had a higher proportion of short shoots and short shoots 
on all rootstocks had smaller final leaf sizes, which confirmed the results of this experiment. On the other hand apple cultivars Gala Must being the vigorous one efficiently absorb the solutes and nutrients that were absorbed by the vigorous apple rootstock Crab Apple. Leaf area and other vegetative growth are also linked with the water supply restriction to the scion induced by anatomical characteristics of the rootstock [9].

Table 2. Leaf area $\left(\mathrm{cm}^{2}\right)$ of apple grafting as affected by rootstocks and cultivars

\begin{tabular}{|c|c|c|c|c|c|c|}
\hline \multirow[b]{2}{*}{ Cultivars } & \multicolumn{5}{|c|}{ Rootstocks } & \multirow[b]{2}{*}{ Mean } \\
\hline & MM111 & MM106 & M26 & M9 & $\begin{array}{l}\text { Crab } \\
\text { apple }\end{array}$ & \\
\hline Treco gala & 31.92 & 29.96 & 27.67 & 26.26 & 35.28 & $30.21 \mathrm{~b}$ \\
\hline Spartan & 18.45 & 18.25 & 14.3 & 12.05 & 21.1 & $16.83 \mathrm{e}$ \\
\hline Mondial gala & 28.96 & 26.60 & 22.84 & 20.6 & 30.64 & $25.93 \mathrm{c}$ \\
\hline Royal gala & 24.06 & 22.4 & 19.86 & 18.05 & 27.96 & $22.46 \mathrm{~d}$ \\
\hline Gala must & 35.66 & 33.55 & 30.11 & 28.01 & 40.8 & $33.62 \mathrm{a}$ \\
\hline Mean & $27.81 \mathrm{~b}$ & $26.15 \mathrm{c}$ & $22.95 \mathrm{~d}$ & $20.99 \mathrm{e}$ & $31.15 a$ & \\
\hline
\end{tabular}

\section{Number of shoots plant ${ }^{-1}$}

The data recorded for number of shoots plant $^{-1}$ is presented in Table 3 was processed for statistical analysis and significant difference was revealed among different cultivars, rootstocks and their interaction. The data regarding number of shoots plant $^{-1}$ indicates that maximum number of shoots plant $^{-1}$ (1.53) was noted in apple rootstock M-26 followed by rootstock MM-111 (1.50), MM-106 (1.42), and M-9 (1.30). Whereas Crab Apple rootstock, had less number of shoots plant ${ }^{-1}$ (1.27). As concerned apple cultivars, Treco Gala attained maximum number of shoots plant ${ }^{1}(1.60)$ which is significantly varied from Spartan cultivar followed by Mondial Gala (1.43), Royal Gala (1.42) whereas the minimum number of shoots plant $^{-1}(1.22)$ was observed in apple cultivar Spartan. As concerned interaction maximum number of shoots plant ${ }^{-1}$ (1.79) was recorded in apple cultivar Treco Gala grafted on M-26 apple rootstock. While the graftage of apple cultivar Spartan on Crab Apple rootstock attained the least number of shoots plant $^{-1}$ (1.00). It is evident from the results that dwarf apple rootstock produce more shoots as it has the habit of forming bush and espalier [10]. It is also cleared from the previous studies of [8] who revealed that scions on low-vigor rootstocks had a higher proportion of short shoots. On the other hand the cultivar Treco Gala, the strain of Gala group produced more branches because of its vigorous nature.

Table 3. Number of shoots plant ${ }^{-1}$ of apple grafting as affected by rootstocks and cultivars

\begin{tabular}{lllllll}
\hline & \multicolumn{5}{c}{ Rootstocks } & \\
\cline { 2 - 6 } Cultivars & MM111 & MM106 & M26 & M9 & $\begin{array}{c}\text { Crab } \\
\text { apple }\end{array}$ & Mean \\
\hline Treco gala & 1.64 & 1.64 & 1.79 & 1.58 & 1.37 & $1.60 \mathrm{a}$ \\
Spartan & 1.39 & 1.22 & 1.47 & 1.06 & 1.00 & $1.22 \mathrm{c}$ \\
Mondial gala & 1.65 & 1.22 & 1.61 & 1.29 & 1.40 & $1.43 \mathrm{~b}$ \\
Royal gala & 1.54 & 1.51 & 1.41 & 1.39 & 1.25 & $1.42 \mathrm{~b}$ \\
Gala must & 1.42 & 1.50 & 1.38 & 1.18 & 1.35 & $1.37 \mathrm{~b}$ \\
\hline Mean & $1.50 \mathrm{a}$ & $1.42 \mathrm{~b}$ & $1.53 \mathrm{a}$ & $1.30 \mathrm{c}$ & $1.27 \mathrm{c}$ & \\
\hline
\end{tabular}




\section{Root length (cm)}

The data recorded for root length is presented in Table 4, was processed for statistical analysis and non-significant difference was revealed among different cultivars, rootstocks and their interaction. Cultivar does not affect the root length of the root stock it is the genetic feature of specific rootstock. The main stub of the rootstock on which the cultivar was grafted shows little changes in term of length while the production of secondary and fibrous rootstock shows great variation among them.
Greater root length was observed in Crab Apple $(18.87 \mathrm{~cm})$ followed by MM111 (9.14 $\mathrm{cm})$ while smaller root length was noted in M-26 $(6.70 \mathrm{~cm})$ and $M-9(6.74 \mathrm{~cm})$ crab apple rootstock penetrate deeper and spread horizontally than M26. These results are in mark up with the previous study who reported the same result for dwarf and semi dwarf rootstock. [11]. He concluded that trees on MM106 had significantly higher root length and root weight which penetrate deeper in soil.

Table 4. Root length of apple grafting as affected by rootstocks and cultivars

\begin{tabular}{llccccc}
\hline \multirow{2}{*}{ Cultivars } & \multicolumn{7}{c}{ Rootstocks } & \\
\cline { 2 - 6 } & MM111 & MM106 & M26 & M9 & $\begin{array}{l}\text { Crab } \\
\text { apple }\end{array}$ & Mean \\
\hline Treco gala & 9.15 & 8.2 & 7.5 & 7.5 & 18.5 & 10.17 \\
Spartan & 8.9 & 7.85 & 5.8 & 5.9 & 17.5 & 9.19 \\
Mondial gala & 9.1 & 8.7 & 6.5 & 6.6 & 18.75 & 9.93 \\
Royal gala & 9.3 & 8.9 & 6.7 & 6.7 & 19.5 & 10.22 \\
Gala must & 9.25 & 9.1 & 7 & 7 & 20.1 & 10.49 \\
\hline Mean & 9.14 & 8.55 & 6.7 & 6.74 & 18.87 & \\
\hline
\end{tabular}

\section{Conclusions and recommendations}

On the basis of experimental results it is concluded that early sprouting was observed for cultivar Treco Gala on apple Rootstock MM106 and on other hand maximum root length and leaf area was observed for Gala Must on Crab apple followed by cultivar Gala Must on MM-111 rootstock. Thus, for quick sprouting in nursery line, cultivar Treco Gala is recommended to be grafted on rootstock MM-106 in areas where there is no problem of root rot disease as MM-106 is susceptible to root rot in humid temperate regions. For humid temperate region rootstock MM-111 is recommended for better growth with Gala varieties.

\section{Authors' contributions}

Conceived and designed the experiments: A Rab, Performed the experiments: F Rabi, Analyzed the data: M Sajid, Contributed reagents/ materials/ analysis tools: $\mathrm{KU}$ Rahman, Wrote the paper: N Bostan.

\section{Reference}

1. Chaudhry MI (1996). Climate and soil requirements for apple cultivation. Horticulture, National Book Foundation. 2(4): 468-470

2. MINFA (2009). Ministry of Food and Agriculture. Division (Economic Wing) Islamabad 92: 48.

3. Teskey BJE (1983). Tree fruit production. Third Edition. The AVI Publishing Co. Inc. Westford, Connecticut 8: 10-12 and 168-173.

4. Robinson T, Andreson L, Azarenko A, Barritt B, Brown G, Cline J \& Crassweller R (2002). Performance of Cornell-Geneva rootstocks in North America NC-140. Rootstock trails. Compact fruit tree 35(4): 99-102 
5. Steel RGD \& Torrie JH (1980). Principles and procedures of statistics, Second edition, New York: McGraw-Hill.

6. Abbas MM, Mohar TA \& Shabir K (2012). Performance of different apple varieties under climatic conditions of Muree Hills. J Agric Res 50(3): 393-401

7. Liaqat UM (2010). Annual progress report of Horticultural section. Agri Res Inst Swat 1-2

8. Michael JC, Seleznyova A, Thorp TG, Blattmann P, Barnett AM, Lowe RG \& Austin PT (2006). Vigor-controlling rootstock affects early shoot growth and leaf area development of kiwi fruit. Tree Physio 26(4): 505-515.

9. Atkinson CJ, Else MA, Taylor L \&. Dover CJ (2003). Root and stem hydraulic conductivity as determinants of growth potential in grafted trees of apple (Maluspumila Mill.). J Exp Bot 54(385): 1221-1229.

10. Susan F (2012). Rootstocks for Fruits. Royal Hort Soci 1-4

11. Sharma DD \& Chauhan JS (2005). Effect of different rootstocks on root distribution of apple. Acta Hort (ISHS) 696: 167-171. 